\title{
TEORIE PEDAGOGIKY
}

UDC.378.02.147:004

DOI: $10.24045 / a p .2017 .4 .2$

\section{UNIVERSITY E-LEARNING: METHODOLOGICAL PROBLEMS AND DIDACTIC PRINCIPLES DEVELOPMENT}

\author{
L. V. Snegireva
}

Candidate of Biological Sciences, assistant professor, ORCID 0000-0002-8935-0511, e-mail: sneglv1@gmail.com, Kursk State Medical University, Kursk., Russia

\begin{abstract}
The author analyzes the university e-learning methodological problems and e-learning didactic principles development. The subject and tasks of the e-learning didactics are considered in the article. The author singles out the e-learning didactic terms, considers e-learning didactics definitions, differences parameters for classical and e-learning didactics. Analyzing modern scientific researches, the author singled out e-learning didactics approaches. Principles supposed to be used as a basis of e-learning didactics are considered, the process of supplementing classical didactic principles and developing new ones in new information and communication technologies society with distance learning, interactive participation and open access to educational content. Perspectives of e-learning didactic principles development are considered.
\end{abstract}

Keywords: e-learning; didactic principles; tasks of didactics; educational process; traditional didactics; differences.

E-learning is an effective instrument of wide range modern higher professional education issues solving $[2 ; 6 ; 11]$. However, the e-learning methodology is not worked out well, and the didactics of e-learning rather refers to art than to science. University pedagogues, using the modern computer technologies capabilities, intuitively seeks the ways of e-learning introduction into practice $[1 ; 5]$. Although, according to the modern researchers opinion, the main thing in e-learning is not the equipment, but the thought of the teacher.

In modern conditions there is a need of:

- effective integration of the external subject-active part of learning process (which is associated with information and material resources that implement pedagogical influences) with the internal part (determined by the individual psychological and personal qualities of the student reflecting the subjectactive part of the learning environment).
- elaboration of a unified integrated information educational environment, use of state information systems for effective management of the education system [7].

The main tasks of electronic didactics are:

- the education structure, volume and content determination according to the ergonomic, health-saving requirements of education in the context of information and communication technologies usage, in appliance with the scientific and technical society level, the students' age and psychological characteristics;

- the development of education new forms and methods to the intensify the educational process;

- information culture development [7].

All listed tasks need the e-learning methodological problems and didactic principles to be worked out. Modern researchers are interpreting the "e-learning" definition in the 
different ways. Also, the different terms: "edidactics" [8] and "didactics of the information society" are used now [3]. To our opinion, the term "didactics of the information society" describes the essence of the analyzed field more objectively, showing the process of supplementing traditional and developing new didactic principles at the information society stage. Terminological differences lead to different didactics definition interpretations.

The first approach considers didactics of the information society as a complex discipline, studying the problem of information technologies introduction to the educational process, automating the data search, storage and processing, information visualization, interactive dialogue, user - computer feedback [7].

According to the second approach, the didactics of the information society is defined as the science, art and engineering of learning [8]. The term of didactic engineering is introduced, that means "the detailed design of educational processes and contains steps for the analysis, development and design of training products, and their use in the educational process" [8]. In our opinion, the third approach is the most balanced. According to it, didactics of the information society reveals the e-learning possibilities in a dynamically functioning information and communication subject environment, aimed at the intellectual and personal development [10].

Various parameters are considered by the researchers to differentiate between traditional didactics and the didactics of the information society. For example, the level of information and communication technologies application and educational system form [8]. There are three levels of information and communication technologies usage in the educational process. The first or low level is characterized by a fragmented application of some digital and multimedia technologies elements in the education. Information and communication technologies are assigned at this stage an auxiliary role that does not affect the quality of the learning process. The second or average level of information and communication technologies usage is represented by a systematic, theoretically based technological and software tools application. It's qualitatively new education level. For example, visualization of processes impossible to observe in real conditions, electronic simulators usage to get professionally significant skills. At the third or high level, all the advantages of information and communication technologies average level are used, supplemented by the distance learning with interactive participation of student and open access to educational content. Face-to-face tutorials in a physical classroom with the low information and communication technologies usage level are based on the traditional didactics principles. The extensive use of information and communications technology with synchronous and asynchronous online communication in an interactive learning environment or virtual communities, in lieu of a physical classroom is already based on didactics of the information society principles [8]. To the other point of view [4], the differences of traditional didactics from the didactics of the information society are based on paradigmatic changes in the education, as

- educational aims, results, forms and methods changes in the e-learning context;

- new educational activity forms appearance;

- non-linear, hypertext, hypermedia educational content presentation instead of a linear or concentric;

- educational content changes (interactive textbooks, manuals and tests elaboration);

- information systems enhancement to automate education processes;

- "virtual world" appearance;

- leveling the teacher' authority [4].

To our mind, both the first and the second of the proposed approaches are debatable.

Approaches are proposed as the modern didactics basis: 1) contextual approach, 2) andragogical approach, 3) developmental approach [9].

These approaches are not specific to the didactics of information society. They make the base of traditional didactics. The didactic principles proposed as a basis for the didac- 
tics of information society are equally universal: [9]

- principle of activity;

- principle of a supportive friendly environment;

- principle of communicative approach;

- principle of individual approach.

All these principles are interpreted in the e-learning framework. Thus, the principle of a supportive friendly environment means that online communication will take away student's fear of failure and his indecision. This statement is only partly true, because online communication really can reduce nervousness, but can't remove it. Remember your reaction to an important phone call or e-mail.

The principle of the individual approach is interpreted as the ability of the student to choose and design the content appropriate to individual needs. We consider this to be true for postgraduate space. In the context of higher education, the principle of individual approach should consist in the educational content selection in terms of accessibility, visibility, practical application. And these functions must be assigned to the teacher, not to the examinee.

The principle of communicative approach is considered from the point of view of students' work results accessibility [9], that means the chance for collective interactive discussion and learner' educational product estimation. We believe that not only students' results are important in terms of accessibility. The fundamental e-learning idea is the educational content availability for any person, regardless of geographical location, social and financial status.

We have some doubts about principle of activity interpretation in the terms of educational content structuring around examinee' main working types. To our mind there is no prevalence of the education activity side over educational content side. And it is reasonable to build all types of students' activities around the content of education.

Thus, the analysis of e-learning didactic principles elaboration problem shows that scientific society still has many questions to solve. Today's e-learning extensive use in the university educational process requires add- ing e-learning new didactic principles, developing classical didactic principles and to adapting them to e-learning process.

Most researchers agree that the e-learning most promising areas are the implicit learning and prime effects patterns usage to combine student's conscious and unconscious experience. Then, there is a need to develop didactic principles that take into account the selforganization processes in the human psyche and social communication in context of total information integration of virtual and physical levels and network global technologies.

In this connection, we have a certainty of e-learning didactic principles thorough elaboration will follow, since the principles are in time and up to society demand.

\section{Bibliography}

1. Белова Т. В., Микрюкова Е. Ю., Тарасюк В. Б., Травкин Е. И. Конвергенция личностноориентированных и групповых образовательных технологий при формировании общепрофессиональных и профессиональных компетенций студентов-бакалавров направления подготовки "Прикладная математика и информатика" // Педагогика сегодня: проблемы и решения: материалы междунар. науч. конф. Чита : Изд-во Молодой ученый, 2017. С. $129-132$.

2. Бурова А. В. Формирование когнитивных умений у учащихся основной школы при выполнении домашней работы по физике: Автореф. Дис. ... канд. пед. наук. - Москва, 2010. $24 \mathrm{c}$.

3. Ибрагимов Г. И. Электронная дидактика и электронное обучение: анализ сущностных характеристик // Информатизация образования: материалы междунар. науч-практ. конф. (Казань, 15-16 июня 2015 г.) - Казань, 2015. C. $147-153$.

4. Роберт И. В. Развитие дидактики в условиях информатизации образования как транферинтеративной области научного познания (концепция). - М. : ИИО РАО, 2014. - 38 с

5. Снегирева Л. В. Электронное обучение в билингвальной среде медицинского вуза // Современное образование. - 2016. - № 3. C. 101-108.

6. Фетисова Е. В., Добрица В. П. Методические приемы формирования математической речи у иностранных студентов // Ярославский педагогический вестник. - 2012. - № 1. - Том II (Психолого-педагогические науки) - С. 193-197.

7. Чиркова Л. Н., Борщик Л. Н. К вопросу о развитии дидактики в условиях электронного образования //Современные информационные 
технологии и ИТ-образование. - 2014. № 10. - С. 221-228.

8. Чошанов М. А. Е-дидактика: Новый взгляд на теорию обучения в эпоху цифровых технологий // Образовательные технологии и общество (Educational Technology \& Society). 2013. - T. 16. - № 3. - С. 684-696.

9. Щенников С. А. Дидактика электронного обучения //Высшее образование в России. 2010. - № 12. - C. 83-90.

10. D'Angelo G. (ed.). From Didactics to e-Didactics, e-Learning Paradigms, Models and Techniques. Napoli: Liguori Editore, 2007. - 404 p.

11. Snegireva L. V. Analysis of mathematical competence mastering as a part of professional competence of medical university clinical psychology faculty students at different educational levels // International Journal of Applied and Fundamental Research. - 2016. - № 5. - C. 322.

\section{Bibliography}

1. Belova T. V., Mikrjukova E. Ju., Tarasjuk V. B., Travkin E. I. Konvergencija lichnostnoorientirovannyh i gruppovyh obrazovatel'nyh tehnologij pri formirovanii obshheprofessional'nyh i professional'nyh kompetencij studentovbakalavrov napravlenija podgotovki "Prikladnaja matematika i informatika" // Pedagogika segodnja: problemy i reshenija: materialy mezhdunar. nauch. konf. - Chita : Izd-vo Molodoj uchenyj, 2017. - S. 129-132.

2. Burova A. V. Formirovanie kognitivnyh umenij u uchashhihsja osnovnoj shkoly pri vypolnenii domashnej raboty po fizike: Avtoref. Dis. ... kand. ped. nauk. - Moskva, 2010. -24 s.

3. Ibragimov G. I. Jelektronnaja didaktika i jelektronnoe obuchenie: analiz sushhnostnyh harakteristik // Informatizacija obrazovanija: materialy mezhdunar. nauch-prakt. konf. (Kazan', 15-16 ijunja 2015 g.) - Kazan', 2015. - S. 147-153.

4. Robert I. V. Razvitie didaktiki v uslovijah informatizacii obrazovanija kak tranfer-interativnoj oblasti nauchnogo poznanija (koncepcija). - M. : IIO RAO, 2014. - 38 s.

5. Snegireva L. V. Jelektronnoe obuchenie v bilingval'noj srede medicinskogo vuza // Sovremennoe obrazovanie. - 2016. - № 3. - S. 101-108.

6. Fetisova E. V., Dobrica V. P. Metodicheskie priemy formirovanija matematicheskoj rechi $\mathrm{u}$ inostrannyh studentov // Jaroslavskij pedagogicheskij vestnik. - 2012. - № 1. - Tom II (Psihologo-pedagogicheskie nauki) - S. 193-197.

7. Chirkova L. N., Borshhik L. N. K voprosu o razvitii didaktiki $\mathrm{v}$ uslovijah jelektronnogo obrazovanija //Sovremennye informacionnye tehnologii i IT-obrazovanie. - 2014. - № 10. S. 221-228.

8. Choshanov M. A. E-didaktika: Novyj vzgljad na teoriju obuchenija v jepohu cifrovyh tehnologij // Obrazovatel'nye tehnologii i obshhestvo (Educational Technology \& Society). - 2013. - T. 16. № 3. - C. 684-696.

9. Shhennikov S. A. Didaktika jelektronnogo obuchenija //Vysshee obrazovanie v Rossii. 2010. - № 12. - S. 83-90.

10. D'Angelo G. (ed.). From Didactics to e-Didactics, e-Learning Paradigms, Models and Techniques. Napoli: Liguori Editore, 2007. - 404 p.

11. Snegireva L. V. Analysis of mathematical competence mastering as a part of professional competence of medical university clinical psychology faculty students at different educational levels // International Journal of Applied and Fundamental Research. - 2016. - № 5. - S. 322.

(C) Snegireva L. V., 2017. 